important function of a lubricant is to prevent the growth of any small welds which may form.

M. Cocks

Research Laboratory,

Associated Electrical Industries, Limited, Aldermaston Court,

Aldermaston, Berks. Feb. 5.

${ }^{1}$ Bowden, F. P., and Hughes, T. P., Proc. Roy. Soc., A, 172, 263 (1939) 'Holm, R., "Electric Contacts", 79 (Uppsala, Almquist and wiksells, 1946).

${ }^{3}$ Kerridge, M., Proceedings - Isotopes Techniques Conference, Oxford, July 1951, 2, 26 (H.M.S.O., 1952). Rabinowicr, E., and Tabor, D. Proc. Roy. Sor., A, 208, 458 (1951).

- MeFarlane, J. S., and Tabor, D., Proc. Roy. Soc., A, 202, 251 (1950). Hirst, W., Kerridge, M., and Lancaster, J. K., Proc. Rny. S.r., A 212, $516{ }^{\circ}(1952)$.

\section{Contrasting Methods of Transmission of Animal Viruses by Mosquitoes}

RECENT investigations ${ }^{1}$ of the mechanism of the transmission of myxomatosis of rabbits by mosquitoes have brought to our attention certain elear-cut differences between the transmission by mosquitoes of those diseases in which a 'biological cycle' occurs in the insect vector, and those in which carriage is purely mechanical. Among the animal viruses, it is only in fowlpox ${ }^{2,3}$ and myxomatosis ${ }^{1,4}$ that mosquito transmission has been conclusively shown to be mechanical in nature. In all the other mosquitotransmitted virus diseases that have been adequately studied (dengue, yellow fever, the viral encephalitides, and Rift Valley fever), there is a 'biological cycle' in the mosquito. Certain implications of these contrasting modes of transmission are summarized in the accompanying table.

\begin{tabular}{|l|c|c|}
\hline & 'Mechanical' & 'Biological' \\
\hline $\begin{array}{l}\text { Source of virus } \\
\text { Speciffeity of mosquito vector }\end{array}$ & $\begin{array}{c}\text { skin lesions } \\
\text { nil } \\
\text { positive }\end{array}$ & $\begin{array}{c}\text { bloodstream } \\
\text { high } \\
\text { negative }\end{array}$ \\
$\begin{array}{l}\text { Extrupted feeding } \\
\text { period) }\end{array}$ & none & present \\
$\begin{array}{l}\text { Arthropod transmission the only } \\
\text { natural mechanism } \\
\text { Multiplication of virus in mosquito }\end{array}$ & no & yes \\
\hline
\end{tabular}

Mechanical transfer by mosquitoes may be $e x$ pected to occur in any disease in which a high skin concentration of a relatively resistant virus occurs. It is not inconceivable that the 'airborne smallpox' reported around fever hospitals ${ }^{5}$ was sometimes mechanically transmitted by mosquitoes, and cowpox may be spread thus among cows, as well as by the milker's hands. Similarly, swinepox may well be transferred from place to place by some more mobile mechanical vector than the hog louse ${ }^{6}$. Mechanical transmission is not incompatible with prolonged infectivity of the mosquito. Brody ${ }^{3}$ obtained positive results with fowlpox at intervals up to forty-one days, and we found ${ }^{1}$ that myxomatosis could be transmitted as long as twenty-five days after the infective feed.

If there is a viræmia but no deposition of virus in the skin, mechanical transmission by mosquitoes occurs only under exceptional conditions? The data of Philip ${ }^{8}$ and St. John et al. ${ }^{8}$ appear to prove that the feeding mechanism of the mosquito is such that regurgitation does not occur. The opportunity for virus in the blood to contaminate the mouthparts appears to be slight, for in many diseases the virus is associated with the cellulan elements of the blood, rather than circulating freely in the plasma ${ }^{10,11}$.
Biting insects which are voracious 'pool feeders' may, on the other hand, be more likely to transfer virus present in the circulation, and this may be the explanation of the mechanical transmission of equine infectious anæmia by tabanid flies and Stomoxys calcitrans, but not by mosquitoes ${ }^{12}$.

Appreciation of the features of mechanical and biological transmission of animal viruses shown in the table may help in elucidating the epidemiology of some of those diseases in which the role of insect vectors is not yet clear.

Department of Microbiology,

Frank Fenner

John Curtin School of Medical Research,

Australian National University, Canberra.

\section{F. DAY}

Division of Entomology,

Commonwealth Scientific and

Industrial Research Organization, Canberra. Feb. 1.

'Fenner, F., Day, M. F., and Woodroofe, G. M., Aust. J. Exp. Biol., 30, 139 (1952).

: Kligler, I. J., and Ashner, M., Brit. J. Exp. Path., 10, 347 (1929).

${ }^{3}$ Brody, A. I., Cornell Univ. Agric. Exp. Stat. Mem. 195 (1936).

- Aragå, H. B., Mem. Inst. Oswaldo Cruz, 38, 93 (1943).

- Millard, C. K., Brit. Med. J., i, 628 (1944).

- Shope, R. E., Arch. ges. Virusforseh., 1, 457 (1940).

' Simmons, J. S., St. John, J. H., and Reynolds, F. H. K., Philipp. J. Sci., 44, 1 (1931).

- Philip, C. B., Ann. Trop. Med. and Parasit., 24, 493 (1930).

- St. John, J. H., Simmons, J. S., and Reynolds, F. H. K., Ann. J. Trop. Med., 10, 237 (1930).

${ }^{10}$ Smith, W., Brit. J. Exp. Path., 10, 93 (1929).

${ }^{11}$ Epstein, B., Fonseca, N. M., and DeRobertis, E., J. Exp. Med., 94, 171 (1951).

${ }^{12}$ Scott. J. W., J. Amer. Med. Vet. Assoc., 9, 448 (1920).

\section{Non-random Distribution of Multiple Mitotic Crossing-over among Nuclei of Heterozygous Diploid Aspergillus}

Somatic, or mitotic, crossing-over ${ }^{1}$ occurs in nuclei of the mycelium of the homothallic ascomyceto Aspergillus nidulans ${ }^{2,3}$, made diploid and heterozygous for known markers by means of a new technique ${ }^{2}$. The asexual Aspergillus niger has now been found to behave in a similar manner; that is, diploids heterozygous for known markers give mitotic recombinants homozygous for one or more of these markers but usually still heterozygous for the others, and therefore undergoing further mitotic recombination. Detailed analysis of mitotia recombinants in A. nidulans further shows that mitotic crossing-over is not distributed at random between the nuclei of the mycelium but tends to be concentrated in a small proportion of them. The kind of evidence on which this conclusion is based is exemplified in the following paragraphs.

A diploid was used, having green conidia and no growth-factor requirement, of genotype

$$
\frac{W a d_{2}}{w A D_{2}}-\frac{y}{Y} \frac{L Y S}{l y s} .
$$

$\left(W / w\right.$, coloured versus white conidia; $A D_{2} / a d_{2}$, independence of, versus requirement for, adenine; $Y / y$, green versus yellow conidia these three loci linked in this order and with map distances of more than $50 \mathrm{cMo}$ between $w$ and $a d_{2}$, and about $7 \mathrm{cMo}$ between $a d_{2}$ and $y, w$ epistatic to $Y / y . L Y S / l y s$ : independence of, versus requirement for, lysine, nonlinked to the others.) In the chromosome carrying 